\title{
UPAYA MENINGKATKAN MOTIVASI BELAJAR SAINS DENGAN MENGGUNAKAN MODEL PEMBELAJARAN KOOPERATIF TIPE STAD PADA SISWA KELAS IV SD NEGERI 101768 TEMBUNG
}

\author{
Zuraidah \\ Surel : zuraidahmpd@yahoo.com
}

\begin{abstract}
This study aims to increase students' motivation to learn science through STAD type cooperative learning. This research is a classroom action research consisting of two cycles. Data collection tool is done by observation and giving questionnaires in each cycle. Based on the results of the questionnaire and observations showing the existence of learning motivation by applying STAD type cooperative learning in increasing the motivation to learn science, it was seen from the average student questionnaire obtained in the initial conditions of 32 students, only 1 student (3.12\%) who had high learning motivation, 8 students (25\%) whose learning motivation was moderate and 23 students (71.87\%) whose learning motivation was low, then in the first cycle it was obtained with the student learning level of 32 students amounting to 10 students (31.12\%) whose learning motivation was high , 12 students (37.5\%) who had moderate learning motivation and 10 students (31.25\%) whose learning motivation was low. On the second cycle, there were 29 students (90.62\%) who had high learning motivation, 3 students $(9.37 \%)$ whose learning motivation was moderate. Can be seen an increase in students from each cycle, so it can be concluded that the application of STAD type cooperative learning can increase motivation to learn elementary school science.
\end{abstract}

Keywords: Motivation, Learning, Cooperative Learning type STAD.

\begin{abstract}
ABSTRAK
Penelitian ini bertujuan untuk meningkatkan motivasi belajar sains siswa melalui pembelajaran kooperatif tipe STAD. Penelitian ini merupakan penelitian tindakan kelas yang terdiri dari dua siklus. Alat Pengumpulan data dilakukan dengan cara observasi dan memberikan angket pada setiap siklus. Berdasarkan hasil angket dan observasi menunjukkan adanya motivasi belajar dengan menerapkan pembelajaran kooperatif tipe STAD dalam meningkatkan motivasi belajar sains terlihat dari rata-rata angket siswa diperoleh pada kondisi awal dari 32 orang siswa, hanya 1 siswa $(3,12 \%)$ yang motivasi belajarnya tinggi, 8 siswa (25\%) yang motivasi belajarnya sedang dan 23 siswa $(71,87 \%)$ yang motivasi belajarnya rendah, selanjutnya pada siklus I diperoleh dengan tingkat belajar siswa dari 32 orang siswa sebesar 10 siswa $(31,12 \%)$ yang motivasi belajarnya tinggi, 12 siswa $(37,5 \%)$ yang yang motivasi belajarnya sedang dan 10 siswa $(31,25 \%)$ yang motivasi belajarnya rendah. Pada sikus II diperoleh 29 siswa $(90,62 \%)$ yang motivasi belajarnya tinggi, 3 siswa $(9,37 \%)$ yang motivasi belajarnya sedang. Dapat terlihat adanya peningkatan siswa dari tiap siklus, sehingga dapat disimpulkan bahwa penerapan pembelajaran kooperatif tipe STAD dapat meningkatkan motivasi belajar sains Sekolah Dasar.
\end{abstract}

Kata Kunci: Motivasi, Belajar, Pembelajaran Kooperatif tipe STAD. 



\section{PENDAHULUAN}

Sains merupakan ilmu yang sangat penting dipelajari yang berhubungan dengan cara mencari tahu tentang alam secara sistematis, sehingga sains bukan hanya penguasaan kumpulan-kumpulan yang berupa fakta-fakta, konsepkonsep dan prinsip-prinsip saja tetapi juga merupakan suatu proses penemuan serta tidak terkesan pasif namun belajar harus aktif dan dinamis. Selain itu suasana kelas yang hidup dapat membuat siswa belajar tekun dan penuh semangat sebaliknya kelas yang suram, menegangkan serta metode pembelajaran yang kurang bervariasi menjadikan siswa kurang bersemangat dan tidak menunjukkan adanya minat untuk belajar.

Berdasarkan hasil wawancara peneliti terhadap guru kelas IV SD Negeri 101768 Tembung, mengatakan bahwa nilai rata-rata ujian IPA/Sains siswa masih dibawah kriteria ketuntasan minimal (KKM) yakni 70. Hal ini dapat terlihat dari motivasi belajar siswa masih rendah yaitu dari jumlah siswa 32 orang yang termotivasi belajarnya hanya $25 \%$ (8 orang) saja, selebihnya $75 \%$ (24 orang) belum termotivasi. Hal ini disebabkan karena guru cenderung menggunakan metode konvensional dalam mengajarkan sains, dimana aktivitas pembelajaran hanya berpusat pada guru sedangkan siswa hanya pasif sehingga siswa merasa bosan dan kurang termotivasi untuk mengikuti pembelajaran, hal ini dapat terlihat dari sedikitnya jumlah siswa yang mengajukan pertanyaan, kalaupun ada siswa yang bertanya hanya dilakukan oleh siswa yang sama. Kemudian dapat dilihat juga dari sikap siswa kurang tekun dan ulet dalam mengerjakan tugas yang diberikan oleh guru, siswa kurang menunjukkan minat yang tinggi terhadap pelajaran yang diberikan, kurangnya kemandirian untuk menguasai materi pelajaran, kurangnya kekreatifan siswa dalam mencari dan memecahkan soal-soal, kurangnya hasrat untuk belajar terutama pada mata pelajaran sains. Oleh sebab itulah peserta didik berperilaku menyimpang pada saat proses belajar mengajar berlangsung karena ada siswa yang ribut didalam kelas, mengganggu teman, bahkan ada siswa yang mengantuk pada saat guru menjelaskan. Dalam hal ini berarti guru kurang mampu dalam menyampaikan pesan-pesan keilmuan dan anak didik dirugikan dan adakalanya guru kurang menguasai konsep pada materi pelajaran sains. Selain itu guru kurang menggunakan media/alat peraga pada saat proses pembelajaran juga dapat mempengaruhi rendahnya motivasi belajar siswa.

Untuk mencapai proses pembelajaran yang dapat meningkatkan motivasi belajar dan membangkitkan gairah siswa dalam belajar sains, guru perlu menerapkan model pembelajaran kooperatif tipe STAD. Model pembelajaran ini merupakan model pembelajaran dengan menggunakan sistem 
kelompok yang menekankan pada adanya aktivitas dan interaksi diantara siswa untuk saling memotivasi dan saling membantu dalam menguasai materi pelajaran guna mencapai prestasi yang maksimal. Dimana siswa dikelompokkan kedalam kelompok yang terdiri antara empat sampai lima orang yang mempunyai latar belajar kemampuan akademik, jenis kelamin, ras atau suku yang berbeda (heterogen).

\section{METODE PENELITIAN}

Penelitian ini adalah jenis Penelitian Tindakan Kelas (PTK) yang mengarah kepada peningkatan motivasi belajar siswa dengan menerapkan pembelajaran kooperatif tipe STAD di kelas dalam pembelajaran sifat-sifat bangun datar kelas VI SDN. 101768 Tembung.

Subjek penelitian ini adalah seluruh siswa kelas VI SDN 101768 Tembung yang berjumlah 25 orang yang terdiri dari 10 orang laki-laki dan 15 orang perempuan.

Defenisi operasional variabel akan memberi kesamaan arti terhadap variabel-variabel penelitian serta untuk menghindari perbedaan pemahaman beberapa istilah yang digunakan dalam judul penelitian. Adapun defenisi dari tiap variabelvariabel dalam penelitian ini adalah :

a. Model Pembelajaran Kooperatif

Tipe STAD yaitu tipe pembelajaran kooperatif yang menekankan pada adanya aktivitas dan interaksi diantara siswa untuk saling memotivasi dan saling membantu dalam menguasai materi pelajaran guna mencapai prestasi yang maksimal.

b. Motivasi Belajar adalah faktor psikis yang bersifat non intelektual dalam hal menumbuhkan gairah belajar dan semangat belajar.

Pelaksanaan penelitian ini direncanakan 2 (dua) siklus. Adapun tahapannya adalah sebagai berikut:

\section{SIKLUS I}

\section{Perencanaan Tindakan}

Penelitian ini penulis membuat rencana sebagai berikut

a. Guru merencanakan akan menyampaikan materi pembelajaran sifat-sifat bangun datar kepada siswa.

b. Guru merencanakan membentuk siswa menjadi 5 kelompok. Setiap kelompok terdiri dari 5 anggota, dimana anggota kelompok mempunyai kemampuan akademik yang berbeda-beda (tinggi, sedang, dan rendah). Jika mungkm, anggota kelompok berasal dari budaya atau suku yang berbeda serta memperhatikan kesetaraan gender.

c. Guru merencanakan akan memberikan tugas kepada kelompok berupa LKK berkaitan dengan materi sifat-sifat bangun datar, mendiskusikannya secara bersama-sama, saling membantu antar anggota lain, serta 
membahas jawaban tugas yang diberikan guru.

d. Guru merencanakan akan memberikan tes I berbentuk pilihan ganda yang terdiri atas 10 butir soal kepada setiap siswa secara individu.

e. Guru merencanakan akan memfasilitasi siswa dalam membuat rangkuman, mengarahkan, dan memberikan penegasan pada materi pembelajaran sifat-sifat bangun datar yang telali dipelajari.

f. Guru merencanakan akan memberi penghargaan kepada kelompok berdasarkan peroleban nilai peningkatan hasil belajar individual dari nilai kemampuan awal ke nilai tes I.

\section{Pelaksanaan Tindakan}

Adapun pelaksanaan

tindakannya adalah sebagai berikut:

a. Guru menyampaikan materi pembelajaran sifat-sifat bangun datar kepada siswa.

b. Guru membentuk siswa menjadi 5 kelompok. Setiap kelompok terdiri dari 5 anggota, dimana anggota kelompok mempunyai kemampuan akademik yang berbeda-beda (tinggi, sedang, dan rendah). Jika mungkin, anggota kelompok berasal dari budaya atau suku yang berbeda serta memperhatikan kesetaraan jender.

c. Guru memberikan tugas kepada kelompok berupa LKK berkaitan dengan materi sifat-sifat bangun datar, mendiskusikannya secara bersama-sama, saling membantu antar anggota lain, serta membahas jawaban tugas yang diberikan guru.

d. Guru memberikan tes I berbentuk pilihan ganda yang terdiri atas 10 butir soal kepada setiap siswa secara individu.

e. Guru memfasilitasi siswa dalam membuat rangkuman, mengarahkan, dan memberikan penegasan pada materi pembelajaran sifat-sifat bangun datar yang telah dipelajari.

f. Guru memberi penghargaan kepada kelompok berdasarkan perolehan nilai peningkatan hasil belajar individual dari nilai awal ke nilai tes I.

\section{Observasi}

Pelaksanaan observasi dilakukan oleh kepala sekolah dan guru bidang studi matematika kelas VI. Tahap observasi sekaligus dilakukan bersamaan dengan tindakan yang dilaksanakan. Observer duduk di dalam kelas mengamati, pengamatan dan pengambilan data dibantu dengan menggunakan kamera dan lembar observasi.

Adapun hal-hal yang diobservasi yaitu :
a. Pelaksanaan tindakan
pembelajaran dengan
menerapkan pembelajaran kooperatif tipe STAD apakah telah sesuai dengan rencana yang telah dibuat sebelumnya
b. Pelaksanaan tindakan dengan menerapkan pembelajaran 
kooperatif tipe STAD apakah telah menunjukkan tanda-tanda kemajuan pada siswa, akan tercapainya tujuan pembelajaran

c. Perubahan sikap siswa dalam belajar matematika khususnya sifat-sifat bangun datar ke arah yang lebih baik

d. Melihat dampak positif dan negatif dari adanya pembelajaran dengan menerapkan pembelajaran kooperatif tipe STAD (Student Team Achievement Division).

\section{Refleksi}

Kriteria keberhasilan/ ketuntasan ditentukan $80 \%$ dari jumlah siswa meningkat motivasi belajar matematika pada sifat-sifat bangun datar. Adapun indikator keberhasilan dari motivasi belajar adalah :

a. Siswa tekun menghadapi tugas

b. Siswa ulet menghadapi kesulitan

c. Siswa menunjukkan minat yang tinggi

d. Siswa mampu bekerja mandiri

e. Siswa cepat bosan dalam tugastugas rutin

f. Siswa dapat mempertahankan pendapatnya

g. Siswa tidak mudah melepaskan hal yang diyakininya. Siswa senang mencari dan memecahkan masalah.

Pada tahap refleksi ini kegiatan yang dilakukan adalah :

a. Mencatat semua keunggulan dan kelemahan selama proses tindakan dan sesudah tindakan dilaksanakan.

b. Melihat, mengkaji dan mempertimbangkan hasil dari tindakan antara peneliti dan guru kelas untuk melihat peningkatan motivasi siswa dalam pembelajaran matematika sifatsifat bangun datar.

Hasil refleksi ini merupakan gambaran keadaan siswa sebagai dasar pengambilan dan perencanaan tindakan pada siklus berikutnya.

\section{SIKLUS II}

\section{Perencanaan Tindakan}

a. Guru merencanakan akan menyampaikan materi pembelajaran sifat-sifat bangun datar kepada siswa. Sebelumnya guru akan menanyakan kepada siswa materi yang belum dipahami siswa setelah menigkuti pembelajaran pada siklus I.

b. Guru merencanakan membentuk siswa menjadi 5 kelompok. Setiap kelompok terdiri dari 5 anggota, dimana anggota kelompok mempunyai kemampuan akademik yang berbeda-beda (tinggi, sedang, dan rendah). Jika mungkin, anggota kelompok berasal dari budaya atau suku yang berbeda serta memperhatikan kesetaraan jender.

c. Guru merencanakan akan memberikan tugas kepada kelompok berupa LKS berkaitan dengan materi sifat-sifat bangun 
datar, mendiskusikannya secara bersama-sama, saling membantu antar anggota lain, serta membahas jawaban tugas yang diberikan guru.

d. Guru merencanakan akan memberikan tes II berbentuk pilihan ganda yang terdiri atas 10 butir soal kepada setiap siswa secara individu.

e. Guru merencanakan akan memfasilitasi siswa dalam membuat rangkuman, mengarahkan, dan memberikan penegasau pada materi pembelajaran sifat-sifat bangun datar yang telah dipelajari.

f. Guru merencanakan akan memberi penghargaan kepada kelompok berdasarkan perolehan nilai peningkatan hasil belajar individual dari nilai tes I ke nilai tes II.

\section{Pelaksanaan Tindakan}

a. Guru menyampaikan materi pembelajaran sifat-sifat bangun datar kepada siswa. Sebelumnya guru akan menanyakan kepada siswa materi yang belum dipahami siswa setelah menigkuti pembelajaran pada siklus I.

b. Guru membentuk siswa menjadi 5 kelompok. Setiap kelompok terdiri dari 5 anggota, dimana anggota kelompok mempunyai kemampuan akademik yang berbeda-beda (tinggi, sedang, dan rendah). Jika mungkin, anggota kelompok berasal dari budaya atau suku yang berbeda serta memperhatikan kesetaraan jender.

c. Guru memberikan tugas kepada kelompok berupa LKS berkaitan dengan materi sifat-sifat bangun datar, mendiskusikannya secara bersama-sama, saling membantu antar anggota lain, serta membahas jawaban tugas yang diberikan guru.

d. Guru memberikan tes/kuis II berbentuk pilihan ganda yang terdiri atas 10 butir soal mengenai sifat-sifat bangun datar.

e. Guru memfasilitasi siswa dalam membuat rangkuman, mengarahkan, dan memberikan penegasan pada materi pembeiajaran sifat-sifat bangun daiar yang telah dipelajari.

f. Guru memberi penghargaan kepada kelompok berdasarkan perolehan nilai peningkatan hasil belajar individual dari nilai tes/kuis I ke nilai tes/kuis II

\section{Observasi}

Kegiatan observasi ini bertujuan untuk mengetahui kesesuaian tindakan dengan rencana yang telah disusun dan guna mengetahui sejauh mana pelaksanaan tindakan dapat menghasilkan perubahan yang diinginkan.

\section{Refleksi}

Pada tahap refleksi ini kegiatan yang dilakukan adalah :

a. Mencatat semua keunggulan dan kelemahan selama proses 
tindakan dan sesudah tindakan dilaksanakan.

b. Melihat, mengkaji dan mempertimbangkan hasil dari tindakan antara peneliti dan guru kelas untuk melihat peningkatan motivasi siswa dalam pembelajaran matematika sifatsifat bangun datar.

\section{Instrumen Pengumpul Data}

Dalam penelitian ini alat yang digunakan adalah :

a. Angket

Angket yang berisi pertanyaanpertanyaan yang membutuhkan jawaban siswa untuk mengukur upaya peneliti melakukan tindakan untuk meningkatkan motivasi belajar dan mengetahui perubahan motivasi belajar siswa pada sifat-sifat bangun datar. Angket terdiri atas 14 butir item pernyataan.

b. Observasi

Observasi dilakukan untuk mengamati perilaku belajar (motivasi) siswa selama proses pembelajaran matematika sifat-sifat bangun datar berlangsung di kelas.

\section{Analisis Data}

Untuk mengetahui peningkatan (perubahan) motivasi belajar siswa secara klasikal, dengan menggunakan rumus (Sudijono, 2009).

$$
P=\frac{f}{n} x 100 \%
$$

Dimana :

$\mathrm{P}=$ angka motivasi

$\mathrm{f}=$ jumlah siswa yang mengalami perubahan

$\mathrm{n}=$ jumlah siswa (aspek)

Untuk menentukan pad persentase skor (angket) motivasi belajar siswa dapat menggunakan rumus sebagai berikut:

Motivasi belajar $=\frac{\text { Skor yang di peroleh }}{\text { Skor maksimal }} \times 100 \%$

\section{HASIL PENELITIAN DAN PEMBAHASAN}

Pembahasan hasil penelitian dilakukan dengan melihat perubahan /peningkatan yang terjadi mulai dari siklus I pertemuan I dan II, dan siklus II pertemuan I dan II. 


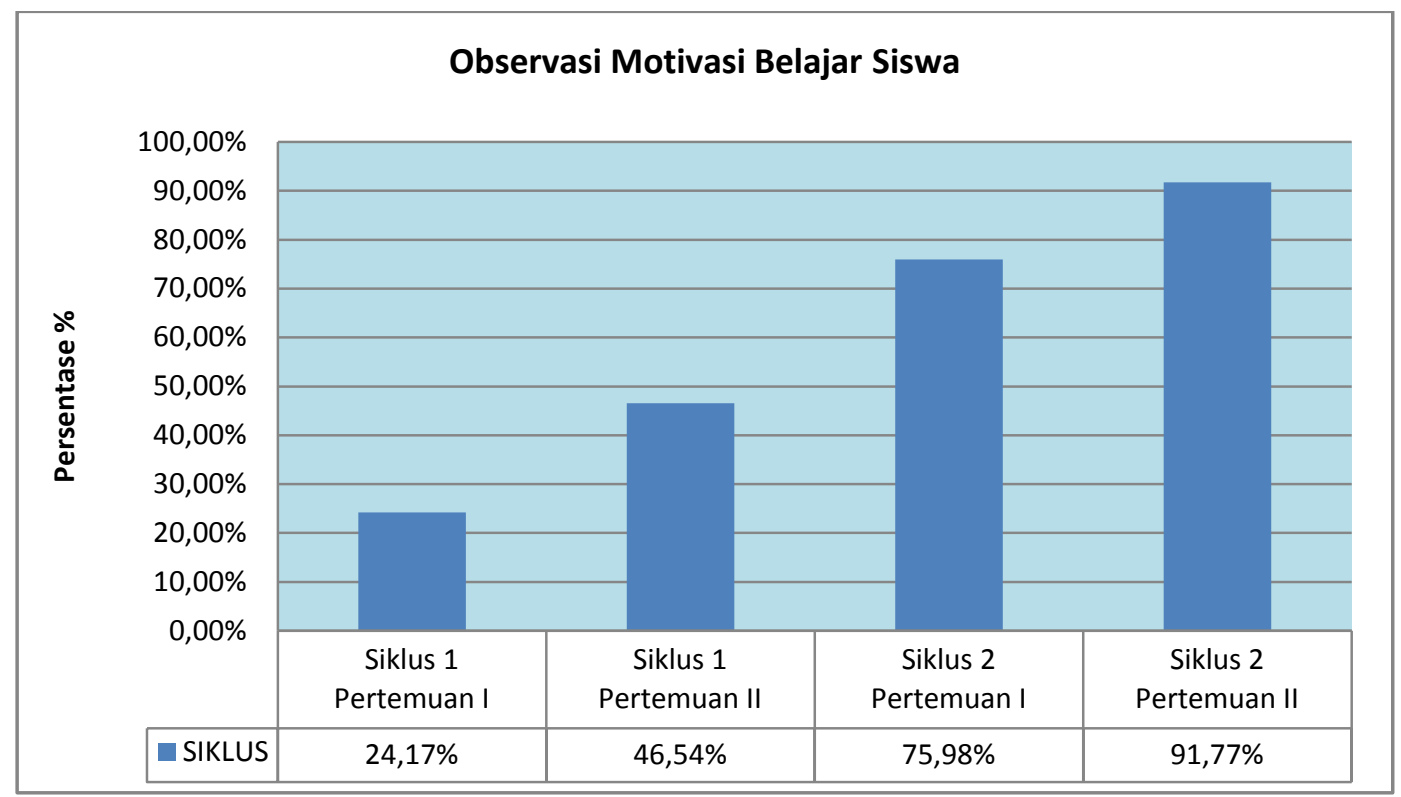

Gambar 1. Grafik peningkatan Hasil Observasi Motivasi Belajar Siswa

Berdasarkan grafik di atas dapat diketahui bahwa pada siklus I hingga ke siklus II mengalami peningkatan, baik dari siklus 1 pertemuan I diperoleh data bahwa $24,17 \%$ yang motivasi belajarnya tergolong kurang, siklus 1 pertemuan II terdapat $46,54 \%$ yang tergolong cukup, pada siklus II pertemuan I terdapat $75,98 \%$ yang tergolong baik, dan pada pertemuan II terdapat $91,77 \%$ yang tergolong sangat baik.

Hasil perubahan tingkat motivasi belajar siswa dari kondisi awal hingga akhir yang diperoleh dari angket dapat dilihat rekapitulasinya pada tabel 4.13 dibawah ini:

Tabel 1. Rekap Perubahan Tingkat Motivasi Belajar Siswa dari Kondisi Awal, Siklus I dan Siklus II

\begin{tabular}{|c|c|c|c|c|c|c|}
\hline \multirow{2}{*}{$\begin{array}{c}\text { No } \\
\text { Urut }\end{array}$} & \multicolumn{2}{|c|}{ Kondisi Awal } & \multicolumn{2}{c|}{ Siklus I } & \multicolumn{2}{c|}{ Siklus II } \\
\cline { 2 - 7 } & Kategori & $\%$ & Kategori & $\%$ & Kategori & $\%$ \\
\hline 1 & Rendah & $\begin{array}{c}23 \\
(71,87 \%)\end{array}$ & Rendah & $\begin{array}{c}10 \\
(31,25 \%)\end{array}$ & Rendah & 0 \\
\hline 2 & Sedang & $\begin{array}{c}8 \\
(25 \%)\end{array}$ & Sedang & $\begin{array}{c}12 \\
(37,5 \%)\end{array}$ & Sedang & $\begin{array}{c}3 \\
(9,37 \%)\end{array}$ \\
\hline 3 & Tinggi & $\begin{array}{c}1 \\
(3,12 \%)\end{array}$ & Tinggi & $\begin{array}{c}10 \\
(31,25)\end{array}$ & Tinggi & $\begin{array}{c}29 \\
(90,62 \%)\end{array}$ \\
\hline
\end{tabular}

Berdasarkan tabel 1 diatas dapat diketahui bahwa pada kondisi awal diperoleh data bahwa 23 orang siswa $(71,87 \%)$ yang motivasi belajarnya tergolong rendah, 8 orang siswa
(25\%) tergolong sedang dan 1 orang siswa $(3,12 \%)$ tergolong tinggi. Dan mengalami peningkatan yang diperoleh data bahwa tidak ada motivasi belajar siswa yang 
tergolong rendah $(0 \%), 3$ orang siswa tergolong sedang $(9,37 \%)$, dan 29 orang siswa $(90,62 \%)$ tergolong tinggi. Untuk lebih jelasnya peningkatan hasil angket motivasi belajar siswa dapat dilihat dari persentase skor (angket) motivasi belajar siswa saat kondisi awal, hasil siklus I dan siklus II, seperti pada gambar diagram batang dibawah ini.

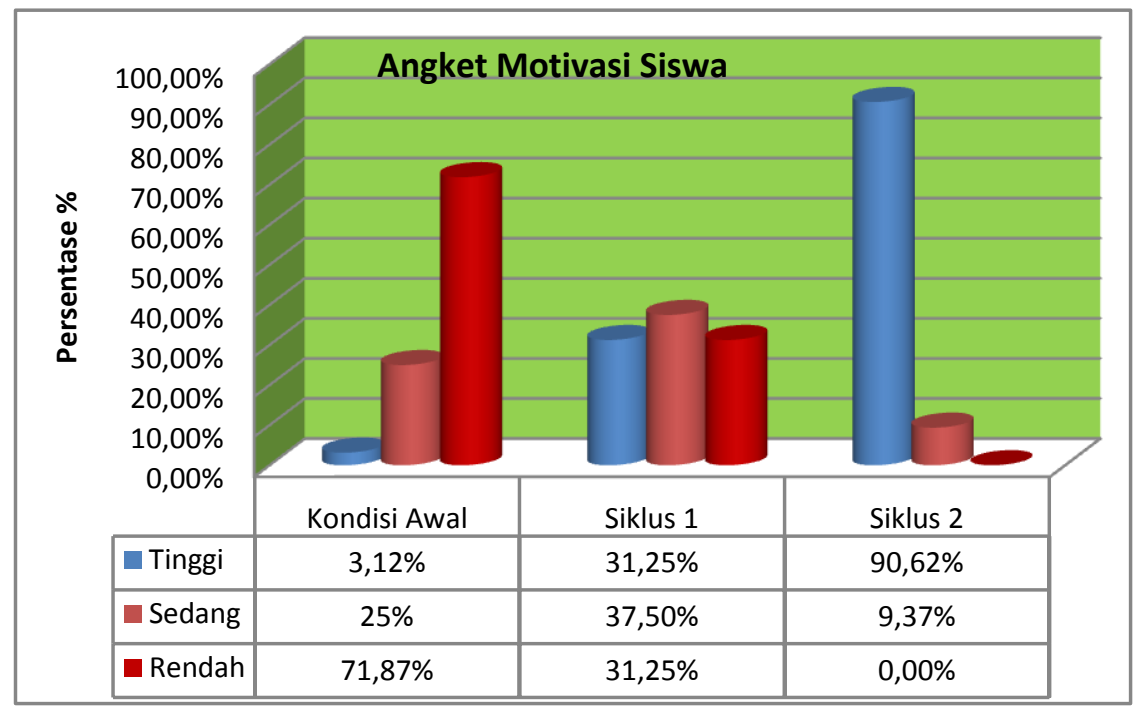

Gambar 2. Grafik peningkatan Motivasi Belajar Siswa

\begin{abstract}
Dari hasil diatas tampak bahwa motivasi belajar siswa mengalami peningkatan dari kondisi awal hingga siklus II. Dengan demikian dapat disimpulkan bahwa terjadi peningkatan motivasi belajar siswa di kelas IV SDN 101783 Saentis.
\end{abstract}

\section{Pembahasan}

Dari hasil observasi motivasi belajar siswa memperlihatkan bahwa terjadi peningkatan belajar siswa diantaranya:

a. Pada siklus I, pertemuan I diperoleh data bahwa $24,17 \%$ yang motivasi belajarnya tergolong kurang. b. Pada siklus I, pertemuan II terdapat $46,54 \%$ yang motivasi belajarnya tergolong cukup

c. Pada siklus II, pertemuan I terdapat $75,98 \%$ yang motivasi belajarnya tergolong baik.

d. Pada siklus II, pertemuan II terdapat $91,77 \%$ yang motivasi belajarnya tergolong sangat baik.

\section{SIMPULAN}

Berdasarkan hasil penelitian tindakan kelas yang dilakukan dengan menerapkan pembelajaran kooperatif tipe STAD pada materi energi bunyi dapat disimpulkan sebagai berikut: (1) Penerapan pembelajaran kooperatif tipe STAD dapat meningkatkan motivasi belajar 
siswa karena dapat memberikan kesempatan kepada siswa untuk belajar aktif bersama teman kelompoknya sehingga siswa tertantang untuk berusaha mengerjakan tugas-tugas dengan mendapatkan nilai yang maksimal dalam belajar; (3) Dari hasil penelitian menunjukkan bahwa terjadi peningkatan motivasi belajar siswa yaitu pada kondisi awal, angka motivasi klasikal diperoleh 3,12\% atau 1 orang dari 32 orang siswa yang mendapat motivasi tertinggi. Sedangkan pada siklus II terjadi peningkatan motivasi berdasarkan hasil angket diperoleh bahwa tidak ada motivasi belajar siswa yang tergolong rendah (0\%), 3 orang siswa tergolong sedang dan 29 orang siswa $(90,62 \%)$ tergolong tinggi; (3) Dari hasil observasi kegiatan mengajar guru pada siklus I pertemuan 1 diperoleh skor 57,5 tergolong rendah, pada siklus I pertemuan 2 diperoleh skor 72,5 tergolong cukup. Dan pada siklus II pertemuan 1 diperoleh hasil observasi kegiatan mengajar guru sebesar 82,5 tergolong baik dan pada siklus II pertemuan 2 mengalami peningkatan sebesar 91,77 tergolong sangat baik.

\section{DAFTAR RUJUKAN}

Aqib, Zainal. 2006. Penelitian Tindakan Kelas. Bandung: Yrama Widya

Arikunto, Suharsimi. 2008. Penelitian Tindakan Kelas. Jakarta: Bumi Aksara
Djamarah, B. Syaiful. 2008. Psikologi Pendidikan. Jakarta: Rineka Cipta

Fathurrohman, P \& Sutikno, S. 2007. Strategi Belajar Mengajar, Bandung: Refika Aditama

Hamalik, Oemar. 2010. Kurikulum dan Pembelajaran. Jakarta: Bumi Aksara

Hariyanto. 2004. Sains untuk sekolah dasar kelas IV. Jakarta: Erlangga

Isjoni. 2009. Pembelajaran kooperatif. Yogyakarta: Pustaka Pelajar

Riyanto, Yatim. 2009. Paradigma Baru Pembelajaran. Jakarta: Kencana

Sanjaya, Wina. 2006. Strategi Pembelajaran Berorientasi Standar Proses Pendidikan. Surabaya: Kencana

Sardiman, A. M. 2007. Interaksi \& Motivasi Belajar Mengajar. Jakarta: PT Raja Grafindo Persada

Soemanto, Wasty. 2006. Psikologi Pendidikan. Jakarta: Rineka Cipta

Suprijono, Agus. 2010. Cooperatif Learning. Yogyakarta: Pustaka Belajar

Uno, Hamzah. 2010. Teori Motivasi \& Pengukurannya. Jakarta: Bumi Aksara

Wena, Made. 2009. Strategi Pembelajaran Inovatif Kontenporer. Jakarta: Bumi Aksara 